\title{
Exploring collective identity of a group of teaching-oriented academics amid research discourse: a Chinese case
}

\author{
Wei Zeng ${ }^{1} \cdot{\text { Letitia } \text { Fickel }^{2}}^{2}$
}

Accepted: 25 May 2021 / Published online: 4 June 2021

(C) The Author(s), under exclusive licence to Springer Nature B.V. 2021

\begin{abstract}
This article explores how a group of teaching-oriented academics - College English (CE) teachers in China - negotiate their collective identity at the workplace amid research discourse. Drawing on an integrated theoretical framework focusing on the interrelationship between discourse, practice, and social networks, the study reveals the field of research where $\mathrm{CE}$ teachers lived imbued by multiple, dynamic discourses and power relations, i.e., the discourse of illegitimate pedagogic research $\mathrm{v}$. the discourse of officially valued research, the discourse of the lower-status department oriented to teaching and public service v. the higher-status, disciplinary department. Drawing upon discursive resources, $\mathrm{CE}$ teachers positioned themselves as marginal pedagogic researchers and inferior CE teachers. Meanwhile, CE teachers constructed their identity-in-practice as pedagogic researchers by developing a pedagogic research community through their daily teaching practice. The contradiction between identity-in-discourse and identity-inpractice suggests the complexity of teaching-oriented, public service-oriented academics' professional life and the predicament they face, such as the limited access to research networks, and the lack of shared understanding in constructing a pedagogic research community. The study argues for more attention to be given to these academics who occupy the bottom of academic hierarchy in higher education context and might be the most vulnerable group in the midst of the COVID-19 pandemic.
\end{abstract}

Keywords Teaching-oriented academics $\cdot$ Collective identity $\cdot$ Research discourse $\cdot$ College English teachers

Wei Zeng

zengwei@swu.edu.cn

Letitia Fickel

letitia.fickel@canterbury.ac.nz

1 College of International Studies, Southwest Universtiy, 400715 Chonging, China

2 College of Education, University of Canterbury, Christchurch, New Zealand 


\section{Introduction}

A substantial body of research into academic identity formation has investigated the multifaceted nature of professional development amid institutional discourse shifting to research productivity. The multiplicity and complexity are particularly addressed in relation to the identity of underrepresented groups, such as those working in regional public universities (Dugas et al., 2018) or academics teaching on foundation studies programs (Strauss, 2020). These academics are generally teaching-focused and are often offered less research opportunities and funds. The study seeks to add to the international understanding of these academics' professional life by providing a vivid Chinese case, that is, how a group of teaching-oriented academics - College English (CE) teachers - negotiated identity amid the research discourse.

CE teachers, known as Public English teachers, teach CE to most undergraduate students in China during their first two years study in universities. It is estimated there are approximately 60,000 CE teachers (Zhang, 2010), forming the largest group of tertiary teachers in China. CE departments are generally viewed as public service units, although they are located in schools of foreign languages that also provide disciplinary education programs of English majors ranging from linguistics, western literature to translation. $\mathrm{CE}$ teachers are typically regarded as instructors rather than academics for being traditionally teaching focused. As China has endeavored to build itself into a research powerhouse of the world and linked its academics' work with the quantity of publications and research grants (Lai, 2010), CE teachers are also under the pressure to publish and compete. However, CE teachers have been widely reported as research-inactive (Barkhuizen, 2009; Borg \& Liu, 2013). With a teaching-intensive background, CE teachers often reported inadequacy of knowledge and skills to undertake systematic research and the lack of competence to reach the research benchmark for promotion (Liu \& Borg, 2014).

We consider the focus on CE teachers particularly significant during the COVID-19 pandemic: CE teachers share quite a few characteristics with certain academics internationally rendered with lowly status, such as those working in foundation studies programs (Strauss, 2020), regional public universities (Dugas et al., 2018), or academic skills support centers (Bennett et al., 2016). These academics usually work with a practical or "training" element, undertake heavy teaching or training load, serve a low-status clientele (e.g., low proficient English learners, adults under-prepared for tertiary study, economically marginalized populations, struggling students), and are more oriented to public service. In the face of the catastrophic impact of the COVID-19 pandemic on colleges and universities, these academics presumably might be the most vulnerable and least protected group; therefore, to understand their professional life and listen to their voices are not just necessary, but urgent.

The study is guided by the question: How do a group of CE teachers negotiate their collective identity as researchers at their workplace amid research discourse? Our focus on collective identity is based on the following considerations. First of all, identity is the place where teachers actually construct meanings of their professional functioning in a changing context (Zeichner, 2007), making it visible how teachers understand themselves, their context, and "the set of power relations as well as the discourses available" to them (Varghese, 2017, p. 46). Secondly, the notion of collective identity is key to understanding "how teachers come to define their identity in shared ways"(Borg, 2016, p. 131). Through interacting with other teachers in their communities or networks, teacher identity forms and develops through the coconstructed meanings and experiences. This is particularly significant when a variety of constructs have been advocated to promote collegial cooperation, such as communities of 
practice (Wenger, 1998), collegial networks (Ginns et al., 2008), professional learning community (Fullan, 2005). In addition, although there is a growing body of literature discussing academics' identity construction in the changing higher education (HE) context (e.g. Boyd \& Smith, 2016; Healey \& Davies, 2019; McCune, 2019), the notion of collective identity has been scarcely explored.

\section{Theoretical framework}

This study draws on the poststructuralist perspective of identity as fluid, contradictory and multifaceted. An integrated framework is adopted to investigate CE teachers' collective identity from three perspectives: identity-in-practice, identity-in-discourse, and interpersonal relationship within the group.

\section{Identity-in-discourse and identity-in-practice}

Identity-in-discourse understands identity to be discursively constructed. Discourses are ways of constituting knowledge and social practices, establishing what is accepted as knowledge and reality in a given society. The socially constructed forms of truth and power come into play with the self-related knowledge and behavioral practices (Foucault, 1978), offering the individual a range of modes of subjectivity (Weedon, 1997). Within a discursive field, not all discourses carry equal weight and power, and identity construction thus "occurs through the identification by the individual with particular subject positions within discourses" (Weedon, 1997, p. 108). The subject position, mediated by discourses and power, describes the ways how people are located to dominant discourses which are associated with specific rights, obligations, limitations, and a conceptual repertoire of feeling, thinking, and behaving (Weedon, 1997). Subject positioning is a process of subjectivation, the mechanisms enabling the individuals to attain a certain mode of being and relate themselves (and others) and judge themselves (and others) according to certain values (Foucault, 2003).

To comprehensively understand the complexity of identity, identity-in-practice should also be considered (Varghese et al., 2005). According to Wenger (1998, pp. 72-85), identity is constituted by practices by which individual develops belonging to a community of practice characterized by "mutual engagement," "joint enterprise," and "shared repertoire." To develop the full membership of a community of practice, individuals need legitimate access to participation which is contingent on social structures and social relations (Lave \& Wenger, 1991).

\section{A social network approach to understanding a group}

The social network approach is to articulate the interactions within the group by focusing on the interdependent relationships among social entities (Granovetter, 1985). It draws attention to the "structure in social action" (Scott, 2000, p. 4) that can be illuminated by the concepts such as density, centralization, and reciprocity. Density refers to "the extent to which all possible relations are present" (Scott, 2000, p. 32). In dense networks, where a high proportion of ties or members maintain direct connections with each other, complex resources move more quickly than in less dense networks (Scott, 2000) and more opportunities for achieving collective goals are generated (Balkundi \& Harrison, 2006). Centralization is concerned with 
"the overall pattern of network integration" (Jewson, 2007, p. 73). It examines how relations and communications within a network are connected with one or a few prominent actors. Closely related to the concept of centralization is the notion of star, the individual or individuals who demonstrate control of information, resources, and influence. A star may have many and frequent connections with members and usually be in the position of leadership and power. Another concept is reciprocity. Reciprocated relationship between actors reflects the two-way nature of the relationship between network members. For example, if teachers develop reciprocated relationships, they have mutual and shared understanding of norms and practices and thus more opportunities to exchange resources (Morrison, 2002; Van Maele et al., 2015)

Social network researchers also use the concept of social capital to examine the content of interactions and "resources embedded in social relations and social structure" (Lin, 2001, p. 24). Occupying a particular position in a social network allows an individual to access particular expertise and resources through one's ties with others. Social capital could be "information, services, material goods, trust, obligations, and prosocial norms" (Small, 2009, p. 18) and expertise (Adler \& Kwon, 2002).

The social network approach needs to take into consideration of the "relational definition of the situation"(McCall, 1970, p. 11). Social relationships are developed from interpersonally negotiated expectations and meanings between people. The core of the relationship is about how to define the relationship. Different definitions of a relationship may imply different interpersonal expectations (Bell \& Healey, 1992). The ongoing and situated interpretative work of individuals and their intersubjective expectations construct networks (Fuhse, 2009) which are embodied within "discursive frameworks" (Emirbayer \& Goodwin, 1994, p. 1427).

\section{Method}

This article is one part of a larger ethnographic study to gain an in-depth understanding of CE teachers' lived experiences amid research discourse. The fieldwork of the research was conducted at the School of Foreign Languages of a university in China. In the following sections, we provide details of our research context, participants, and process in addition to an explanation of the relationship between researchers and the researched.

\section{Context: College English Department in TSU}

The School of Foreign Languages (SFL) in TS University (TSU) was composed mainly of two English education departments: English Major Department (EMD), which provided courses to English majors, and the staff in EMD were called disciplinary academics; College English Department (CED) - the focus of the study - was oriented to non-English major undergraduates in TSU. CED of TSU stood out as a typical case that shared common characteristics of CE teachers' workplace: TSU was a research-oriented university where research performance had become an important part in the appraisal of its teachers; SFL was one of the largest foreign language education institutions in China, boasting research strength in linguistics and western literature; CED was one of the largest CE departments where ninety-one CE teachers worked. In this regard, the research is an instrumental case study (Stake, 2005), the aim of which is to understand the phenomenon experienced by teaching-oriented, public serviceoriented academics during the educational change. 


\section{Researchers and the researched}

The larger ethnographic research was undertaken by the first author as her doctoral study. She conducted all the data collection work at the field. She was an insider of the research: previously working in CED as a CE teacher, and knowing the participants for many years. Her insider role and perspectives augmented the understanding of teachers' lived experiences by building up trust and rapport with the participants and gaining access to many aspects of their lives. At the same time, our working as a team helped to take outsider perspectives to the researched and thus strengthen the rigor of the study. We acknowledge the participants' experiences were intricately interwoven with our first author's own experience. We make our positions as transparent as possible in a way that is congruent with the poststructuralist notion of identity as dynamic, contextual, and relational, so that readers can make their own interpretations.

\section{Participants and process}

Data collection proceeded through three nodes of social network mapping interviews suggested by Trotter (1999). In the first node, we used purposive sampling to select ten focal teachers representing a range of gender, age, and positions in CED. Each participant was required to put on names of their social ties on a concentric circle according to the closeness of their research relationships (see Fig. 3 in Appendix). Following the mapping, an in-depth, semi-structured interview was carried out by our first author. The interview questions were framed around how teachers built up research ties with each person they identified, how they interacted in research, why they put names at certain places and why they went to some people not others. The interviews also addressed teachers' conceptions of and engagement in research because we thought different research attitudes and behaviors might impact the nature and configuration of their networks.

The ten focal teachers in the first node produced a number of people they recognized as research ties, the so-called alters. The alters included fourteen CE teachers, among whom we selected another ten CE teachers for the second node of network mapping interviews. After two nodes, we found there were no new $\mathrm{CE}$ teachers emerging from networks, then we decided to select another eleven CE teachers among those who were excluded from any networks. These teachers did not produce any new CE teachers as their alters. We thus concluded the thirty-one CE teachers' social networks from three nodes were sufficient to understand the overall interpersonal relationships among $\mathrm{CE}$ teachers.

In addition to regular audiotaped interviews with participants, our first author took the role of participant observer by undertaking certain teaching load, observing and interacting with teachers at and after work. Relevant texts produced by the institutions were also collected, such as recruitment and promotion policies, teachers' professional development plans, etc.

Over $20 \mathrm{~h}$ of interview, data were transcribed and returned to the participants for verification before the data were analyzed. The data analysis started from understanding participants' conceptions of and attitudes toward research and research engagement, resulting in a set of themes, e.g., research-teaching nexus, types of research engagement, reasons for doing or not doing research, comparison of CED and EMD, under which the corresponding extracts from all the interviews had been assembled. 
Next, we sketched each participant's social network, or the personal network (LeCompte et al., 1999) and started with a priori codes suggested by the literature on social networks. These codes focused, for example, on each alter's locus-as a department or school or beyond-school network member-as well as on reasons for establishing ties, reasons for attaching "importance" or "less importance" to particular ties, the frequency of interaction and content of interaction. We then subcoded data to address finer categories - for instance, by designating reasons for establishing tie with greater precision, such as alter's characteristics, prior professional relationship, friendship, and shared values and by identifying the specific forms of interaction content, e.g., encouragement, support in teaching, and doing research together.

Finally, drawing on thirty-one personal networks, we delineated the full connections among the participants and their CE alters, or the full relational network (LeCompte et al., 1999), so that we could understand the overall social structure of their interpersonal interactions.

We presented participants' research networks through "collective stories" in which the "protagonist is a collective" and individuals are "coparticipants of a collective story"(Richardson, 1997, p. 14). The basic information of the "coparticipants" is listed in Table 1. According to Richardson, writing collective stories is to give voice to a group that is often silenced or marginalized by dominant narratives; therefore, we crafted the stories in relation to silence, marginalization, conflicts, alienation, or alignment experienced by the participants. The stories drew upon the themes developed from the full relational analysis of CE teachers' research networks, i.e., the characteristics of density, centralization, reciprocity, and location of participants' alters. These themes allowed us to organize CE teachers' narratives into three collective stories. The stories portrayed how participants described their research relationship with CE colleagues, how they perceived themselves when being included in other CE teachers' research networks and how they understood the relationship with the ties they considered with significance.

Table 1 Background information of the "coparticipants" (in the sequence of their appearance in stories)

\begin{tabular}{|c|c|c|c|c|c|}
\hline Pseudonym & Gender $(\mathrm{M} / \mathrm{F})$ & Years of working & $\begin{array}{l}\text { Working } \\
\text { department }\end{array}$ & Position in administration & Academic rank \\
\hline Xia & $\mathrm{F}$ & Approx.15 & CED & & Lecturer \\
\hline Lian & $\mathrm{F}$ & $20+$ & CED & & Lecturer \\
\hline Lin & $\mathrm{F}$ & $20+$ & CED & Former vice dean & Professor \\
\hline $\mathrm{Na}$ & $\mathrm{F}$ & Approx.10 & CED & & Lecturer \\
\hline Tang & $\mathrm{F}$ & Approx.15 & CED & Head teacher & Associate Prof. \\
\hline Jing & $\mathrm{F}$ & Approx.15 & CED & & Lecturer \\
\hline Hong & $\mathrm{F}$ & $20+$ & CED & & Lecturer \\
\hline Hui & $\mathrm{F}$ & Approx.10 & CED & & Lecturer \\
\hline Sen & $\mathrm{F}$ & $20+$ & CED & & Lecturer \\
\hline Min & $\mathrm{F}$ & Approx.10 & CED & & Lecturer \\
\hline Yue & $\mathrm{F}$ & Approx.15 & EMD & & Professor \\
\hline $\mathrm{Fu}$ & M & Approx.15 & $\mathrm{CED} / \mathrm{EMD}$ & Head teacher & Associate Prof. \\
\hline Feng & $\mathrm{F}$ & Approx.10 & CED/EMD & & Associate Prof. \\
\hline Jia & $\mathrm{F}$ & Approx.10 & CED & & Lecturer \\
\hline
\end{tabular}




\section{Stories on and behind maps}

\section{"It's just teaching research."}

Our invitation for drawing a research network map was not well received at the beginning. A $\mathrm{CE}$ teacher refused to join in the research, saying "I didn't do any research. I don't know how to draw it." Xia, a middle-aged CE teacher, claiming she did not do any research, agreed to draw the map because she thought she could help our research as "a negative case." More often, CE teachers agreed to take an interview, but refused to draw the map. For example, a senior teacher, Lian, gave us a blank map. When she was reminded that she was identified as a research tie by some participants, she quickly dismissed it and said, "those are not research at all. Such activities make no sense."

Whether drawn or not, the maps produced by thirty-one participants led us to draw a sociogram (see Fig. 1) showing the full relational map of CE teachers' research interactions. The sociogram drew most CE teachers as isolated members as most of them never appeared in any participant's network. Among participants, they and their alters were also involved in merely dyadic connections. None of the connections among them was particularly intense. This reveals that the group was of low density in research activities.

In Fig. 1, Lin stood out as a star as she had the most direct and indirect links with teachers. On the SFL website, Lin was introduced as a Star Teacher of the province, the first prize winner of national teaching excellence, the leader of a national $\mathrm{CE}$ reform, the winner of numerous teaching awards. Eight participants drew Lin into their maps, and the rest, although they did not draw Lin in their maps, had alters who were connected with Lin. For example, as Fig. 1 shows, Na identified Tang as her research tie. Tang identified Lin as a research tie and emphasized Lin's leadership in organizing $\mathrm{CE}$ reform research activities that she, $\mathrm{Na}$, and other $\mathrm{CE}$ teachers were all involved in.

Lin's leadership in CE reform was recognized by many participants who referred to their interactions with Lin in the CE reform teaching research, such as compiling textbooks, implementing innovative teaching approaches, writing teaching research papers, and attending $\mathrm{CE}$ reform conferences. A middle-aged CE teacher, Jing, was still grateful when talking about Lin's help to improve her "content-based" teaching practice,

When Lin knew my experiment of the teaching approach, she thought it was interesting and kept asking me to write a paper to share with other teachers. By her push, I wrote a paper. Later, she funded me to give a speech on the CE conference. Because of her encouragement, I found what I did was significant and valuable.

However, Jing did not deem Lin as an important research tie. She put Lin on the outskirt of her map, because, Jing said, "these were not real research." Such

\footnotetext{
${ }^{1}$ Teaching research in many ways shares the characteristics of pedagogic research suggested by Macfarlane (2011). Compared with the subject-based disciplinary research, such research tends to be local, bounded by the context where it rises, and done with researchers' own teaching and students (Tierney, 2020). It also encompasses the characteristics of practitioner research, such as "tthe insider status of the researcher, the centrality of action, the requirement of spiraling self-reflection on action, and the intimate, dialectical relationship of research to practice" (Anderson \& Herr, 1999, p. 12), or "practical inquiry" (Richardson, 1994). Ambiguous as the term is, the institutional script of it in TSU and SFL is the teaching inquiry not published in the required indexed journals. We adopted the ethnographic meaning of teaching research and used teaching research and pedagogic research interchangeably.
} 

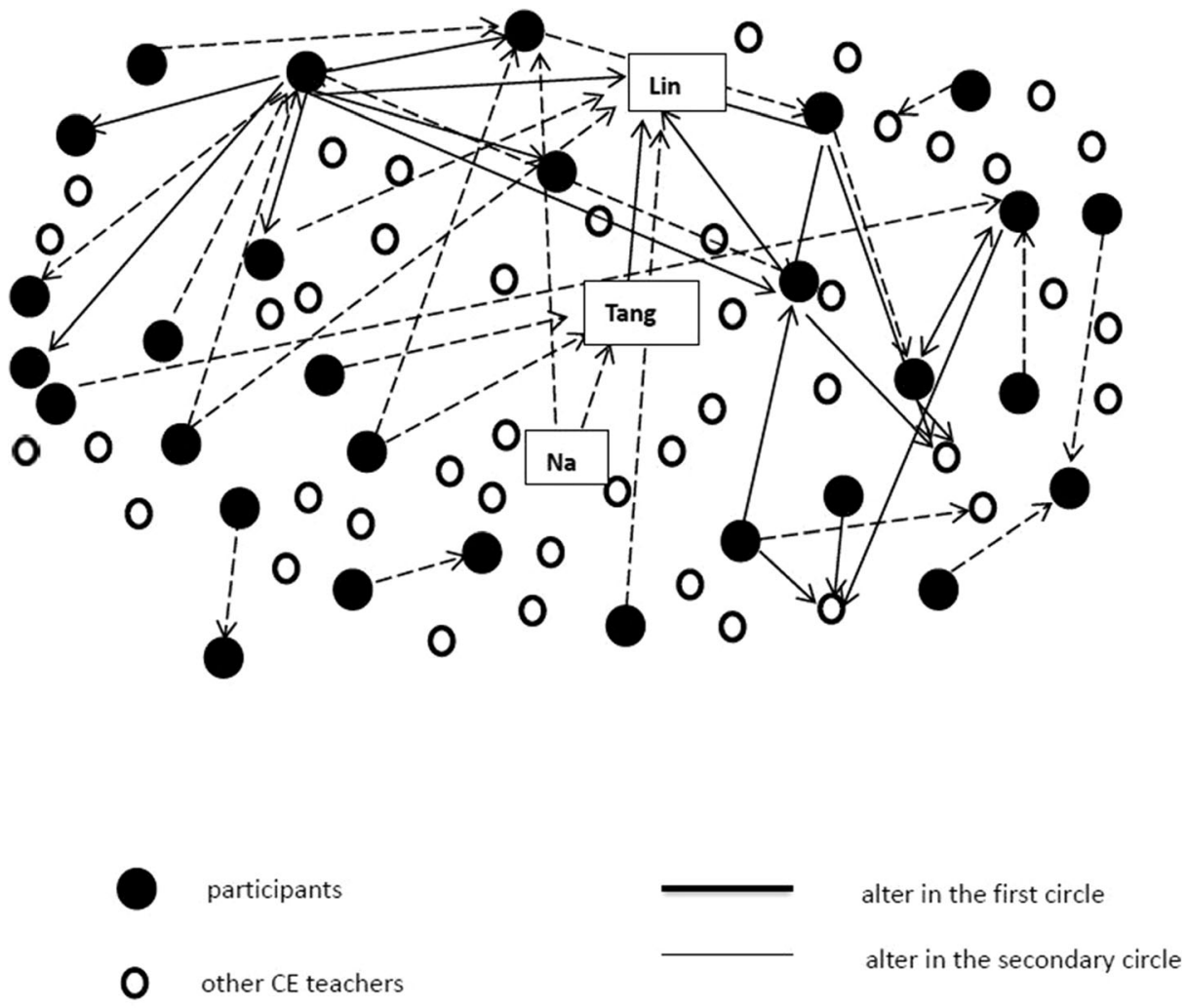

- - alter in the distant circle

Fig. 1 Full relational research network of CE teachers

ambivalence toward Lin's research leadership is illustrated by Fig. 1, in which all the connections with Lin are in thin or broken lines. Not a single connection is drawn in bold line, as all the participants who recognized Lin's leadership in teaching research put her at the secondary or distant circle of their maps.

At the first glance of Fig. 1, it is easy to conclude this was a decentralized group of low density in research interactions, suggesting $\mathrm{CE}$ teachers had minimal research interactions and there was no research leader among them. The interviews reveal this was the result of $\mathrm{CE}$ teachers' negotiated meanings about what counted as research. Being subjected to the dominant discourse that defined research in the form of high ranking publications and funding, $\mathrm{CE}$ teachers positioned themselves marginal pedagogic researchers; hence, they unanimously positioned Lin. The pedagogic research leader, at the outskirt and reluctantly agreed to draw maps because what they had done was "just teaching research."

In contrast to their self-positioning as marginal or non-researchers, CE teachers constructed the identity- in- practice as active pedagogic researchers. Being led by Lin and cooperating with colleagues, they constructed a community of practice in which they mutually engaged in the joint enterprise of CE reform and shared repertoire of doing pedagogic research and improving students' learning. 


\section{"She included me? I don't think we did research!"}

The largest personal network was drawn by a senior CE teacher, Hong (see Fig. 2). On her map, more than a dozen of CE teachers were identified as alters, among whom we chose some as our participants. For example, a young CE teacher Hui. According to Hong, Hui and her both were interested in teaching writing and had communicated quite often in this aspect. Hong called the interactions with Hui "the research of how to improve teaching." A senior CE teacher Sen was also identified by Hong. Sen and Hong shared "strong interests" in teaching English pronunciation. They cooperated in the joint teaching and a survey of students' pronunciation learning, which resulted in a joint paper and a conference speech.

However, neither Hui nor Sen considered Hong as their research ties. Hui was surprised to know she was included in Hong's network and said, "she included me? I don't think we did research. We just worked together in CE reform teaching research." As for Sen, she did not even draw the map. During the interview, Sen clearly knew Hong wrote her into her map and said,

I guess Hong must have included me in her map. We have communicated quite often about teaching...these can't be seen as real research.

Sen continued to explain her understanding of research,

By research I mean there must be theoretical advancement based on empirical data. It must be published on good journals, otherwise it can only be called reflection. For me... or from the official level, research must be in the form of high-level publications. Yes, I do reflect on my teaching, but I don't think what I did and what I reflected is research.

Another alter of Hong's network, Jing, identified Hong as one of her research ties. Jing collaborated with Hong in applying an innovative teaching approach which was "excitedly welcomed by the students." Jing's innovation experience was reported on two CE reform conferences where she "received very positive feedbacks from other CE teachers." For this, Jing commented on herself a "reflective teacher" and a "positive learner" who often studied pedagogies and educational theories. "However," Jing continued, "when talking about research, I'm ashamed. I didn't do research well." She stopped for a few seconds, went on saying,

but I don't think I have never done research. I am doing something. I tried different (teaching) approaches. This is useful for my teaching... and it is based on my reflection, thinking and reading. I also observed other teachers' classes. My teaching is not done casually or based on nothing. For me, this is also a kind of research.

Abruptly, Jing blamed herself for looking for an excuse,

I know the report is unqualified for A, or B-level journals. My theoretical foundation is not strong and my writing is not very good either. I am doing something, but still can't make any high-level publications. These are excuses. I shouldn't look for the excuse for myself.

During the interview, Jing turned to ask the interviewer how she defined research, if writing to the high-ranking journals was the only form of research and if the efforts to understand the classroom and improve the teaching practice counted as research. Jing described her puzzle, 
I do constantly reflect (on teaching) ... my problem is whether I should just try to improve my understanding of classroom or pursue the form.

To Jing, the "form" referred to the scholarly writing for high-ranking publications. What she had done was "experience-based" writing directly aimed to improve her "understanding of classroom." Apparently, Hong and Jing's perception toward research contradicted with that held by Hui and Sen who perceived research in the form of high-ranking publications. The contradiction can be explained by the classification of jiaoyan and keyan in the documents of TSU and SFL. Keyan, or scientific research, assessed research performance in publications on high-ranking journals, such as those indexed by SSCI or CSSCI (Chinese Social Sciences Citation Index), and funding at provincial or national level; jiaoyan, or teaching research, included textbooks compiling, teaching awards, and teaching research publications uncharted in those indexes. Keyan accounted for decisive weighing in the appraisal of teachers' work. Such classification led to CE teachers' conflicting identification of research networks. Consequently, the sociogram in Fig. 1 indicates low reciprocity between members, suggesting the majority of teachers were one-way connected. This highlights the lack of mutual understanding in defining research and research relationship among CE teachers.

The low reciprocity of recognizing each other's research efforts again reveals the conflict between CE teachers' identity-in-discourse and identity-in-practice, which became the source of the contradictory, fragmented collective identity. There was no shared conception within the group toward who counted as research ties. Some participants deviated from the dominant discourse by drawing the largest network centered on pedagogic research, while some of her alters aligned with the dominant discourse by either drawing a blank map or feeling surprised at being included in pedagogic research networks. The conflicts and struggles were explicitly expressed through the heterogeneous emotions experienced by Jing who confidently talked about her teaching while feeling "ashamed" about her research, who described how her innovative teaching was "excitedly" received by her students and other CE teachers at the same time blaming herself for "not doing well" and "trying to look for the excuse."

\section{"She is more influential in research."}

On eighteen out of twenty-five drawn maps, the closest ties of the participants were located in the other English education department, English Major Department (EMD). These important alters shared the same characteristics: being professors or experts in linguistics or literature. Some participants were PhD students in linguistics. Their most important research ties turned out to be their supervisors working in EMD. For most non-PhD participants, they also identified those EM teachers as important ties. A case in point is the network of Min, a young CE teacher.

Min wrote five alters' names including Yue, an EM professor in the closest circle (see Fig.

2). Yue was Min's teacher before and often "encouraged" Min to do research. Min described how they interacted,

We don't meet face to face. Mostly we just communicate by phone. She often told me about academic lecture information and asked me to attend...we didn't work in any research project. Her influence mainly comes from her encouragement. She occasionally called me and asked about my work, making me feel I should do research. Her push is the strongest influence I get from her. 


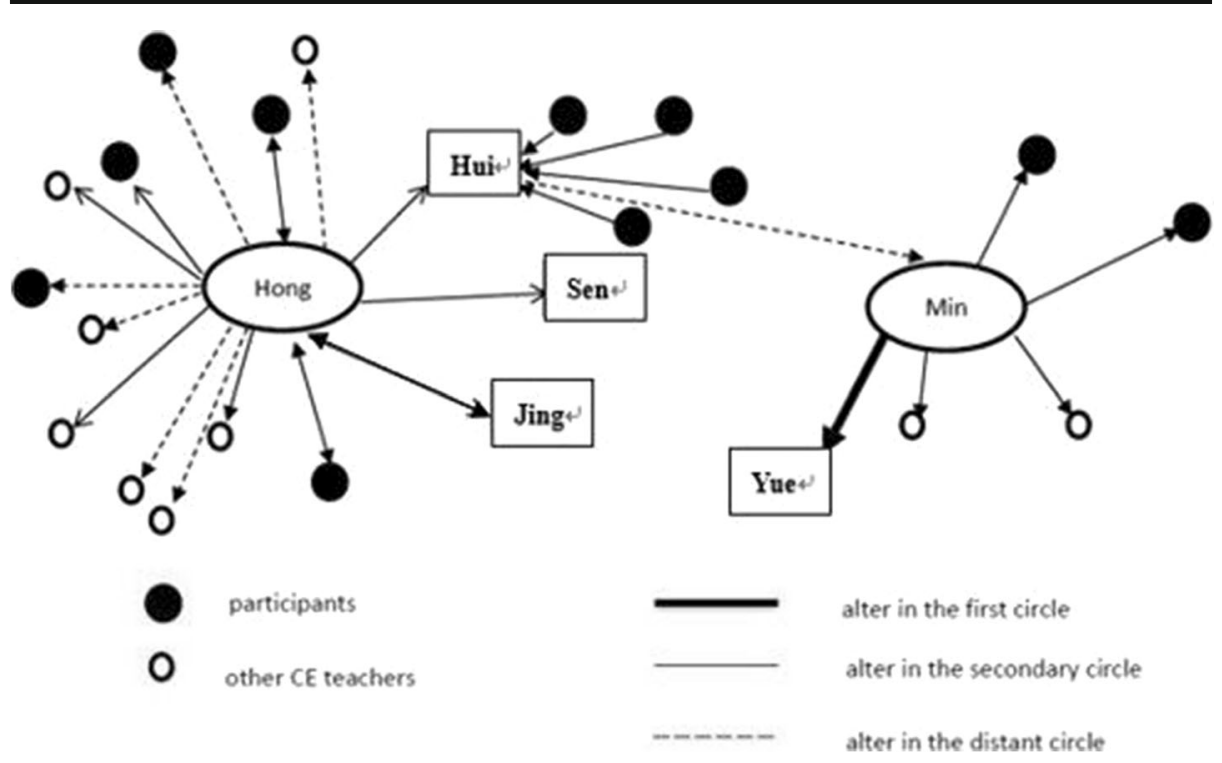

Fig. 2 Personal research networks of Hong and Min

The other alters on Min's map included three CE teachers. Their interactions were centered on teaching and $\mathrm{CE}$ reform teaching research. Their frequent interactions had made them good friends and they often "learnt from each other." When asked why she put CE colleagues at the outskirt although they had frequent interactions, Min explained these activities were not scientific research and Yue was more influential in research,

You (the interviewer) ask about research, don't you? Yue is a research expert and more influential in research. As for CE colleagues, they can't help me in scientific research.

Like Min, most participants built up ties with EM experts during their previous teacher-student relationship. Similarly, none of them was involved in research activities with their closest ties from EMD and the encouragement from these experts was reported to be the major help. With these experts, the participants felt encouraged but "not improved in research." In addition, the interactions seemed to be oriented to teaching rather than research. For example, Hong described how her teaching was influenced by one of her close ties, a professor in lexicology,

His way of teaching influenced my teaching. If I were to run a course, I would go to attend his lecture to see how he organized the class. He might have influenced my pedagogy, but without specific research impact.

Being "more influential" is not the only reason for CE teachers' positioning of EM teachers at the center. According to $\mathrm{Fu}$, a young $\mathrm{CE}$ teacher, "the good researchers were constantly transferred to EMD," which makes it seem that "CE teachers only need to teach well." The "good researchers" were CE teachers who obtained a doctorate. Feng, who had transferred to EMD, was one of them. She recalled how she felt when she was a CE teacher seven years ago,

I always repeated teaching the same textbook and the same content to four to five classes, week after week, year after year. I felt sick of it. 
Feeling "trapped" and "sick," Feng hoped to "walk forward." She decided to undertake $\mathrm{PhD}$ research in literature. After completing the PhD study, Feng was transferred to EMD and found EM students "apparently different." She said,

It's easy for me to communicate with EM students because they have a good command of English...CE students are less motivated. With EM students, I can ask them to read, question and discuss literature work.

The "less motivated" CE students were seen as one of the reasons for CE teachers' inactive research engagement. A young $\mathrm{CE}$ teacher Jia explained doing research had less impact on teaching "especially for CE students" because CE students' motivations and attitudes toward English learning "were not comparable to EM students."

Feng was transferred to EMD after becoming a "good researcher." A similar job arrangement is found in Liu and Dai's study (2003). In every Chinese university they investigated, the teachers with advanced degrees were usually arranged to work in EM departments, while teachers without advanced degrees were arranged to teach CE. Not surprisingly, Feng asked our first author during the interview, "you will come to EMD after study, won't you? Otherwise, it is a waste to stay in CED."

This story suggests the discourse about CE teachers' lower status at the workplace. Subjected to the discourse, CE teachers positioned themselves inferior to EM teachers. Therefore, they located EM teachers at the center of their networks because EM teachers are "more influential," even though they had minimal research interactions. The unequal arrangement of research resources for CE teachers, such as the less engaging students and the deprivation of expertise of "good researchers," also created subjectivity of "CE teachers only need to teach well." This, against the discourse devaluing pedagogic research knowledge, further reinforced CE teachers' self-positioning as marginal. The subjection to multiple discourses was explicitly demonstrated on Feng who decided to "move forward" from lower-status CED by acquiring the doctorate preferred by the dominant discourse and considered staying in CED "a waste" by suggesting the interviewer to transfer to EMD.

The full relational network mapping also shows EMD was a disciplinary research community to which CE teachers had limited access. They were non-participants of officially valued research. For example, their interactions with EM professors were mostly oriented to teaching or remained at encouragement level. Feng's case further demonstrates the access to EMD was heavily guarded: only after acquiring a doctorate in literature, can a CE teacher like Feng be moved to the higher status EMD.

\section{Discussion and implications}

Using social network mapping, our research identified a pedagogic research community selfinitiated by $\mathrm{CE}$ teachers. In practice, $\mathrm{CE}$ teachers were active participants in teaching and pedagogic research activities; simultaneously, they positioned themselves marginal researchers and inferior CE teachers.

The case of CE teachers indicates the structural barriers faced by teaching-focused, public service-oriented academics when they attempt to approach and enact research development. In addition to the heavy teaching load, the lack of financial support as found in previous studies (e.g. Dugas et al., 2018; Murray et al., 2009), these academics have limited access to research resources in terms of interpersonal relationship. Cooperation with research qualified staff has 
been argued as an important means to develop research capacity (Tellmann et al., 2020). In this case, the unequal job arrangement by the organization generated limited social capital for $\mathrm{CE}$ teachers to develop research capacity; for example, the "good" researchers were transferred to work in higher status disciplinary department of EMD. Furthermore, the explicit and implicit unequal treatment from the organization created a collective sense of second-rate to disciplinary academics, or even a "waste," resonating the common feelings of "not quite university people" and being "turned away" by other staff members (Strauss, 2020, p.6) or experiences of invisibility and valuelessness (Bennett et al., 2016). According to social network studies, the lack of access to interacting with disciplinary academics and the self-knowledge as second-rate might bond the interactions within the closed groups (Crossley, 2013). This provides an explanation for the lack of research leadership and mentors reported among CE teachers (Bai et al., 2014; Barkhuizen, 2009; Xu, 2014).

The group of CE teachers is in sharp contrast with the group of teaching-only academics in MacKenzie et al.'s study (2010) where members' strong bond facilitated trust and security that helped them to develop into a learning community. Although the group in our study bears a number of features described by Heinrich (2017) as a strong teaching group, such as strong leadership in CE reform activities, active collegial networks with a clear sense of improving student learning, the engagement in this group does not work to empower but marginalize $\mathrm{CE}$ teachers. We explain the difference as resulting from the difference in lens. The lens of identity-in-discourse articulates the detrimental effect of research dominant discourse on cultivating teaching communities. Embedded within the hierarchical discursive context about what is a "real" academic and "real" research, a teaching community might have its leadership and expertise unrecognized by its members. The contradiction of members' self-positioning might constrain the development of a collective view of research as well as the shared understanding of their mutual engagement, resulting in the lack of reciprocal recognition and trust. This finding is in line with Heinrich's study (2017) in which even the teaching group with the highly collaborative culture reported conflicts and dissatisfaction caused by the hierarchical status between research and teaching, discounting the claim that teaching-oriented academics might be freed from dominant research focus and build "a different kind of research community" (Cotton et al., 2018, p.13).

The findings add to the recent discussions about the position and quality of pedagogic research in HE (Cotton et al., 2018; Evans et al., 2020; Tierney, 2020). The study indicates the perception of pedagogic research as being of lower value is prevalently embedded in institutional structure (Cotton et al., 2018), in which academics perceive research and teaching as competing rather than complementary. This seems to be the result of the explicit division of research by the institution into jiaoyan and keyan, supporting Cotton et al.'s (2018) opinion that separates strands of roles in universities have reinforced rather than reduce the overwhelming focus on the high-status activity of research. This finding problematizes Boyer's (1990) intention to define different types of scholarship by differentiating teaching scholarship from scientific research scholarship. Such efforts seem to increase parity of teaching and research, imposing challenges to developing shared understandings of pedagogic research and building pedagogic research communities. Although Evans et al. (2020) propose the concept of "integrated academic," suggesting interdisciplinary communities of practice across research and pedagogical teams be promoted, our findings show that teaching-focused, public serviceoriented academics who occupy the bottom of the academic hierarchy have neither access to interdisciplinary research networks nor legitimacy to construct a pedagogic research community. 
Taken as a whole, the study suggests at least four divides developing for these academics. The first is the divide between the rhetoric of a greater focus on research productivity and the actualities of teaching-oriented academics' work (Dugas et al., 2018). The second is shaped by the first, that is, the gap between the calls for more research output and high-quality teaching and the support these academics receive from their workplace. The third is that teaching-oriented academics collectively experienced a divide between their identities - practical identity as teachers and pedagogical researchers - and discursive identity as illegitimate, second-class researchers. This leads to the fourth divide, one that breaks up the teaching community in which members hold contradictory perception toward their joint teaching and pedagogic researching enterprise. The four divides illustrate the factors that can confound the well-intentioned initiatives to improve teaching quality and promote teaching and research as complementary activities (Jenkins, 2002 ). Moreover, the power-laden environment is unhelpful for these academics to develop research capacity. Without the involvement of these academics, it is highly impossible to have a holistic and first-hand understanding of the fields they are working for.

The specificity of the Chinese context renders CE teachers some uniqueness. Unlike many of their western counterparts employed by temporary forms of contract (e.g., Castellacci \& Viñas-Bardolet, 2020; Strauss, 2020), CE teachers seldom reported job insecurity in terms of being laid off. CE teachers in our case were all recruited before or at the time when HE institutions in China started the transition from the danwei system, the "paternalistic management" model by the Chinese government (Huang et al., 2016, p. 4) to the new personnel system based on contract-based employment and performance-related pay. The legacy of danwei system ensures these academics lifetime job security while they are subject to performance-based evaluation. This supports Castellacci and Viñas-Bardolet's (2020) argument that academics with a permanent contract tend to experience less job insecurity than those employed with casualization. On the other hand, CE teachers demonstrated little resistance. Whether unanimously positioning themselves at the marginal places or leaving CED to EMD by acquiring a doctorate, $\mathrm{CE}$ teachers demonstrated strong conformity. This conformity might suggest identity is merely a developmental issue. With the growth of time and experience, academics learn to accept the reality (Dugas et al., 2018). It is also possible that occupying the lowest status at the workplace, these academics are lack of faith in transforming the context (Strauss, 2020). A more convincing explanation would be the powerful bureaucratic forces rooted in the danwei system and the Chinese culture valuing individuals' subordination to collective goals (Huang \& Guo, 2019). In this regard, more studies are needed to explore different cultural contexts so as to draw a broader picture of these academics' professional life.

In the face of the COVID-19 pandemic, it could be argued these academics may be facing the worsening situation of shrinking resources. It is high time to pay attention to their quandary in professional development; after all, the students they work for are usually the most vulnerable and disadvantaged and occupy a large number in colleges and universities. Acknowledging these academics' contribution to quality teaching and allowing them equal opportunities could improve chances for our educational success and social equity. Although the substantial change in the HE context appears unlikely at any time soon, the institutions could start a small step toward mitigating divisions between academics. One would be to follow the disciplinary innovation reported by 
Han and $\mathrm{Wu}$ (2015) in which academics were engaged in transdisciplinary dialogue by relocating the staff offices and integrating multiple disciplines into the new curriculum. This can not only promote communication between academics from different departments and mobilize resources; more importantly, the inclusion of lower-status academics into the new curriculum can help to develop a sense of belonging to the workplace and alleviate their marginalization.

Acknowledgements This work was supported by Fundamental Research Funds for the Central Universities (SWU1309245) and Humanity and Social Science Youth foundation of Ministry of Education of China (19XJC740003). We also wish to thank the two anonymous reviewers for providing insight and expertise that greatly improve the article.

\section{Appendix}

\section{About mapping}

Please write down the names of the people who you associate with in research activities. Supposing you are at the centre of the concentric circle (Fig. 3), put the names in terms of "importance" of research relationship at an appropriate place in relation to the centre.

1. You may put the names straddling across two rings.

2. The people you associate with include but are not limited to your colleagues (department, school, and university), family or friends, etc.

3. The following questions may help you identify the people:

- Who influences your research attitude or behaviour?

- Who do you turn to or discuss with if you have problems or ideas in doing research?

- Who do you choose to cooperate with if you apply for a research project?

- Who do you exchange research resources with? For example, with whom would you like to share if you know a useful website or a good book?

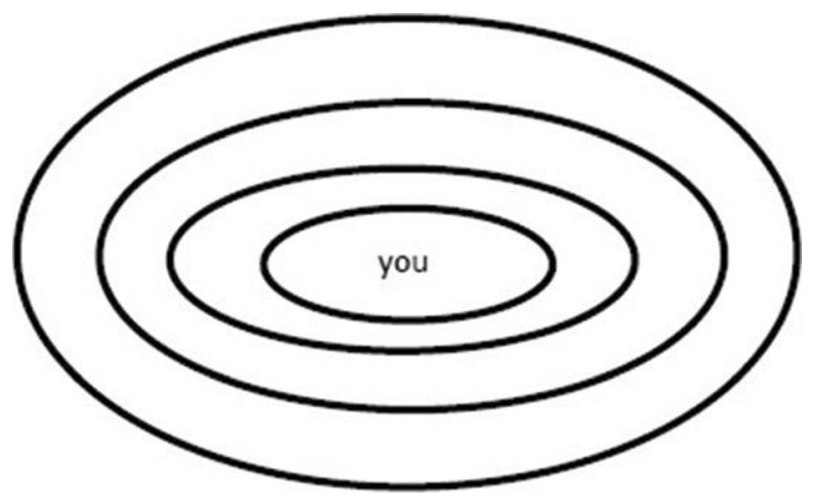

Fig.3 A research network map 
- Who do you exchange research information with? For example, the information about academic conference, courses, lectures activities or publications. Who do you turn to if you want to know such information?

- Who do you like to share happiness and unhappiness of doing research with?

\section{References}

Adler, P. S., \& Kwon, S.W. (2002). Social capital: prospects for a new concept. Academy of Management Review, 27(1), 17-40. https://doi.org/10.2307/4134367.

Anderson, G. L., \& Herr, K. (1999). The new paradigm wars: is there room for rigorous practitioner knowledge in schools and universities? Educational Researcher, 28(5), 12-40. https://doi.org/10.3102/ 0013189 X028005012.

Bai, L., Millwater, J., \& Hudson, P. (2014). Chinese TEFL teachers' perceptions about research and influences on their research endeavours. Teacher Development, 18(3), 349-368. https://doi.org/10.1080/13664530. 2014.919344.

Balkundi, P., \& Harrison, D. A. (2006). Ties, leaders, and time in teams: strong inference about network structure's effects on team viability and performance. Academy of Management Journal, 49(1), 49-68. https://doi.org/10.5465/amj.2006.20785500.

Barkhuizen, G. (2009). Topics, aims, and constraints in English teacher research: a Chinese case study. TESOL Quarterly, 43(1), 113-125. https://doi.org/10.1002/j.1545-7249.2009.tb00231.x.

Bell, R. A., \& Healey, J. G. (1992). Idiomatic communication and interpersonal solidarity in friends' relational cultures. Human Communication Research, 18(3), 307-335. https://doi.org/10.1111/j.1468-2958.1992. tb00555.x.

Bennett, R., Hobson, J., Jones, A., Martin-Lynch, P., Scutt, C., Strehlow, K., \& Veitch, S. (2016). Being chimaera: a monstrous identity for SoTL academics. Higher Education Research and Development, 35(2), $217-228$.

Borg, S. (2016). Identity and teacher research. In G. Barkhuizen (Ed.), Reflections on language teacher identity research (pp. 126-132). Routledge.

Borg, S., \& Liu, Y. (2013). Chinese college English teachers' research engagement. TESOL Quarterly, 47(2), 270-299. https://doi.org/10.1002/tesq.56.

Boyd, P., \& Smith, C. (2016). The contemporary academic: orientation towards research work and researcher identity of higher education lecturers in the health professions. Studies in Higher Education, 1-18. https:// doi.org/10.1080/03075079.2014.943657

Boyer, E. (1990). Scholarship reconsidered: priorities of the professoriate. Carnegie Foundation for the Advancement of Teaching.

Castellacci, F., \& Viñas-Bardolet, C. (2020). Permanent contracts and job satisfaction in academia: evidence from European countries. Studies in Higher Education, 1-15. https://doi.org/10.1080/03075079.2019. 1711041

Cotton, D. R. E., Miller, W., \& Kneale, P. (2018). The Cinderella of Academia: Is Higher Education pedagogic research undervalued in UK research assessment? Studies in Higher Education, 43(9), 1625-1636. https:// doi.org/10.1080/03075079.2016.1276549.

Crossley, N. (2013). Interactions and juxtapositions: Conceptualizing 'relations' in relational sociology. In C. Powell \& F. Dépelteau (Eds.), Conceptualizing relational sociology: ontological and theoretical issues (pp. 123-144). Palgrave Macmillan.

Dugas, D., Stich, A. E., Harris, L. N., \& Summers, K. H. (2018). "I'm being pulled in too many different directions": academic identity tensions at regional public universities in challenging economic times. Studies in Higher Education, 45(2), 312-326. https://doi.org/10.1080/03075079.2018.1522625.

Emirbayer, M., \& Goodwin, J. (1994). Network analysis, culture, and the problem of agency. American Journal of Sociology, 99(6), 1411-1454. https://doi.org/10.1086/230450.

Evans, C., Howson, C. K., Forsythe, A., \& Edwards, C. (2020). What constitutes high quality higher education pedagogical research? Assessment and Evaluation in Higher Education. https://doi.org/10.1080/02602938. 2020.1790500 .

Foucault, M. (1978). The history of sexuality. In An introduction (Vol. 1). Pinguin Books.

Foucault, M. (2003). The ethics of the concern for self as a practice of freedom. In P. Rabinow \& N. Rose (Eds.), The essential Foucault: selections from the essential works of Foucault 1954-1984. The New Press. 
Fuhse, J. A. (2009). The meaning structure of social networks. Sociological Theory, 27(1), 51-73. https://doi.org/ 10.1111/j.1467-9558.2009.00338.x.

Fullan, M. (2005). Professional learning communities writ large. In E.-W. Barbara, D. Richard, \& R. E. Eaker (Eds.), On common ground: the power of professional learning communities (pp. 209-223).Solution Tree Press.

Ginns, P., Kitay, J., \& Prosser, M. (2008). Developing conceptions of teaching and the scholarship of teaching through a graduate certificate in higher education. International Journal for Academic Development, 13(3), 175-185. https://doi.org/10.1080/13601440802242382.

Granovetter, M. (1985). Economic action and social structure: The problem of embeddedness. American Journal of Sociology, 91(3), 481-510. https://doi.org/10.1086/228311.

Han, C., \& Wu, Z. (2015). Teacher learning across boundaries: a challenge to the legitimacy of language teachers' disciplinary knowledge. Asia-Pacific Journal of Teacher Education, 43(3), 225-242.

Healey, R. L., \& Davies, C. (2019). Conceptions of 'research' and their gendered impact on research activity: a UK case study. Higher Education Research and Development, 38(7), 1386-1400. https://doi.org/10.1080/ 07294360.2019 .1657804 .

Heinrich, E. (2017). Teaching groups as midlevel sociocultural contexts for developing teaching and learning: a case study and comparison to microcultures. Higher Education Research and Development, 364(4), 702715. https://doi.org/10.1080/07294360.2016.1208641.

Huang, Y., \& Guo, M. (2019). Facing disadvantages: the changing professional identities of college English teachers in a managerial context. System, 82, 1-12. https://doi.org/10.1016/j.system.2019.02.014.

Huang, Y., Pang, S.-K., \& Yu, S. (2016). Academic identities and university faculty responses to new managerialist reforms: experiences from China. Studies in Higher Education, 43(1), 154-172. https:/doi. org/10.1080/03075079.2016.1157860.

Jenkins, A. (2002 ). Pedagogic research at Brookes: Achievements, opportunities and questions. Paper presented at the Teaching Forum 50.

Jewson, N. (2007). Cultivating network analysis: rethinking the concept of "community" within communities of practice. In J. Hughes, N. Jewson, \& L. Unwin (Eds.), Communities of practice: Critical perspectives (pp. 68-82). Routledge.

Lai, M. (2010). Challenges to the work life of academics: the experience of a renowned university in the Chinese mainland. Higher Education Quarterly, 64(1), 89-111. https://doi.org/10.1111/j.1468-2273.2009.00432.x.

Lave, J., \& Wenger, E. (1991). Situated learning: legitimate peripheral participation. Cambridge university press.

LeCompte, M. D., Schensul, J. J., Singer, M., Trotter II, R. T., \& Cromley, E. K. (1999). Mapping social networks, spatial data, and hidden populations. Altamira.

Lin, N. (2001). Social capital: a theory of social structure and action. Cambridge University Press.

Liu, Y., \& Borg, S. (2014). Tensions in teachers' conceptions of research: insights from College English teaching in China. Chinese Journal of Applied Linguistics, 37(3). https://doi.org/10.1515/cjal-2014-0018.

Liu, R., \& Dai, M. (2003). Research on status quo and development strategies for foreign languages teaching reforms in Chinese universities. Foreign Languages Teaching and Research Press.

MacKenzie, J., Bell, S., Bohan, J., Brown, A., Burke, J., Cogdell, B., et al. (2010). From anxiety to empowerment: a learning community of university teachers. Teaching in Higher Education, 15(3), 273-284. https:// doi.org/10.1080/13562511003740825.

McCall, G. J. (1970). The social organization of relationships. In G. McCall, M. McCall, N. Denzin, G. Suttles, \& S. Kurth (Eds.), Social relationships (Vol. 334, pp. 3-34). Aldine.

McCune, V. (2019). Academic identities in contemporary higher education: sustaining identities that value teaching. Teaching in Higher Education, 1-16. https://doi.org/10.1080/13562517.2019.1632826

Morrison, E. W. (2002). Newcomers' relationships: the role of social network ties during socialization. Academy of Management Journal, 45(6), 1149-1160. https://doi.org/10.2307/3069430.

Murray, J., Campbell, A., Hextall, I., Hulme, M., Jones, M., Mahony, P., et al. (2009). Research and teacher education in the UK: building capacity. Teaching and Teacher Education, 25(7), 944-950.

Richardson, V. (1994). Conducting research on practice. Educational Researcher, 23(5), 5-10. https://doi.org/10. 3102/0013189X023005005.

Richardson, L. (1997). Fields of play: Constructing an academic life. Rutgers University Press.

Scott, J. (2000). Social network analysis: a handbook (2nd ed.). Sage.

Small, M. L. (2009). Unanticipated gains: origins of network inequality in everyday life. Oxford University Press.

Stake, R. E. (2005). Qualitative case studies. In N. Denzin \& Y. Lincoln (Eds.), The Sage handbook of qualitative research (3rd ed., pp. 443-446). Sage Publications. 
Strauss, P. (2020). Not quite university people? Academics teaching on foundation studies programmes in New Zealand universities. Higher Education Research and Development, 39(5), 1013-1025. https://doi.org/10. 1080/07294360.2019.1699030.

Tellmann, S. M., Røsdal, T., \& Frølich, N. (2020). Professional educational programmes under pressure. Organizational challenges related to strengthening research. Studies in Higher Education, 1-11. https:// doi.org/10.1080/03075079.2019.1711039

Tierney, A. (2020). The scholarship of teaching and learning and pedagogic research within the disciplines: should it be included in the Research Excellence Framework? Studies in Higher Education, 45(1), 176-186. https://doi.org/10.1080/03075079.2019.1574732.

Trotter, R. T. (1999). Friends, relatives and relevant others: conducting ethnographic network studies. In M. D. LeCompte, J. J. Schensul, M. Singer, R. T. Trotter II, \& E. K. Cromley (Eds.), Mapping social networks, spatial data, and hidden populations (pp. 1-49). Altamira Press.

Van Maele, D., Moolenaar, N. M., Daly, A. J., DiPaola, M., \& Hoy, W. (2015). All for one and one for all: a social network perspective on the effects of social influence on teacher trust. Leadership and School Quality, $171-196$

Varghese, M. (2017). Language teacher educator identity and language teacher identity: towards a social justice perspective. In G. Barkhuizen (Ed.), Reflections on language teacher identity research (pp. 43-48). Routledge.

Varghese, M., Morgan, B., Johnston, B., \& Johnson, K. A. (2005). Theorizing language teacher identity: three perspectives and beyond. Journal of Language, Identity \& Education, 4(1), 21-44. https://doi.org/10.1207/ s15327701jlie0401 2.

Weedon, C. (1997). Feminist practice and poststructuralist theory (2nd ed.). Blackwell.

Wenger, E. (1998). Communities of practice: learning, meaning, and identity. Cambridge University Press.

Xu, Y. (2014). Becoming researchers: a narrative study of Chinese university EFL teachers' research practice and their professional identity construction. Language Teaching Research, 18(2), 242-259. https://doi.org/10. 1177/1362168813505943.

Zeichner, K. (2007). Accumulating knowledge across self-studies in teacher education. Journal of Teacher Education, 58(1), 36-46. https://doi.org/10.1177/0022487106296219.

Zhang, J. (2010). A study on status quo and problems in college English teacher team construction. China Higher Education, (17), 53-54.

Publisher's note Springer Nature remains neutral with regard to jurisdictional claims in published maps and institutional affiliations. 